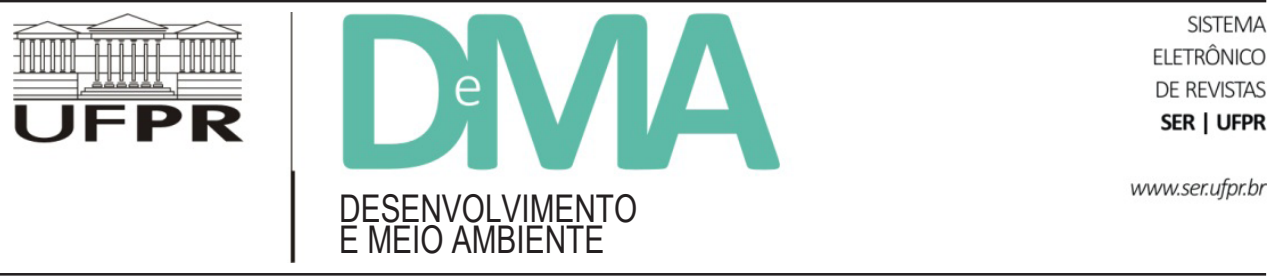

\title{
Depoimento de Maria do Rosário Knechtel ${ }^{1}$
}

A homenagem que se presta à querida Profa. Magda se reveste de uma magnitude de profissional criativa, inteligente, pulsante, buscando sempre novos valores, com amorosidade e, ao mesmo tempo, com muita energia. Dessa forma, escolhia e empurrava as pessoas e as suas ideias para o alcance concreto de seus objetivos.

Ao longo de sua rica história, em que se insere sua ideia e vontade de criar e fundar o Curso de Doutorado em Meio Ambiente e Desenvolvimento da UFPR, então com a aquiescência e incentivo do Reitor Faraco e Vice-Reitor Mário Pederneiras, fui indicada para integrar a comissão de criação do referido Programa.

Desde a primeira reunião do Programa, da qual participei, já com a valiosa e simpática presença de Magda, tive a felicidade de conhecê-la. Após as discussões iniciais, logo se estabeleceu uma interação acadêmica, amistosa, incessante e, imediatamente, ela empurrou-me para assumir a disciplina de Educação Ambiental. Sendo eu socióloga e pedagoga, os estímulos advindos de sua inteligência, atualidade, visão de mundo e de Brasil em relação ao meio ambiente e à educação, impulsionaram-me à busca de fundamentos e de avanços no sentido de a Educação Ambiental vir a cumprir seu papel nodal e estratégico no preenchimento da lacuna existente nos estudos da relação natureza-sociedade.

A inscrição da disciplina de Educação Ambiental no MADE deve-se em grande parte à Magda, dado seu conhecimento, sensibilidade e credibilidade na educação. Assim, oportunizou-se a construção epistemológica, metodológica, interdisciplinar do conhecimento apoiado em princípios, conceitos, valores habilidades e atitudes reconhecidos na Conferência de Estocolmo, que mostrou a necessidade de uma consciência "esclarecida" do indivíduo em relação à natureza e o meio ambiente para sua preservação e conservação (UNESCO, 1972).

Evidenciam-se os sinais de comprometimento, de vontade e de contribuição da E.A. na formação e qualificação de doutores, profissionais de meio ambiente, na produção científica, nas ações de enfrentamento e de busca de soluções aos problemas da realidade socioambiental. Mediante a problematização da realidade Sociedade - Natu-

\footnotetext{
${ }^{1}$ Socióloga e Pedagoga. Mestre em C. Sociais. USP. Dra. em Sociologia da Educação - UFSM - RGS; PhD em Sociologia e Ed. Permanente-Madrí e Barcelona; PhD em Sociologia e Ed. Ambiental - Berlim-Alemanha; professora de Ed. Ambiental e Ecoformação; Pesquisadora. Orientadora de dissertações, teses do PPGMADE-UFPR.
} 
reza, a concepção histórico-crítica, construtivista, crítico-transformadora(práxis), com os enfoques dominantes -cognitivo, reflexivo-criativo, epistemológico, interdisciplinar em face da complexidade a educação ambiental desenvolve suas atividades e práticas socioeducativas ambientais.

Estas atividades e práticas, desenvolvidas nos seminários com dinâmicas interativas, práticas pedagógicas e de pesquisa interdisciplinar e cons- trução coletiva de conhecimento, vêm buscando alcançar os objetivos da Educação Ambiental. Desse modo, a E.A. pensa, constrói e produz o conhecimento no contexto do Doutorado-MADE. Eis, querida MAGDA, a homenagem da Educação Ambiental, que você sempre prestigiou e ajudou a criar!

Você é um ícone para nós - a verdadeira educadora! 